\title{
OPTIMALISASI PENDISTRIBUSIAN BARANG MENGGUNAKAN METODE GOAL PROGRAMMING (STUDI KASUS: PT. WULANTIKA UTAMA)
}

\author{
S. S. Novrianti ${ }^{1}$, A. I. Jaya ${ }^{2}$, dan Resnawati ${ }^{3}$ \\ 1,2,3 Program Studi Matematika Jurusan Matematika FMIPA Universitas Tadulako \\ Jalan Soekarno-Hatta Km. 09 Tondo, Palu 94118, Indonesia. \\ 1srisakina_Yp@yahoo.com, 2jayaindraagus@gmail.com,3r35n4w4t1@yahoo.com
}

\begin{abstract}
PT.Wulantika Utama is one of distributor in Palu who distribute products from factories to retailers. The purpose of this research are to maximize the distribution numbers of trucks and minimize the cost of distribution. Goal Programming is a method that can solve the problem with more than one purpose. Goal Programming model formulation in this study consists of 5 priority and 5 constraint functions. The fifth priority is the storage capacity, the number of trucks used for the distribution of goods to Donggala, Ampana, Poso, and cost targets are minimum distribution. Constraint function consists of inventory in the warehouse, the number of trucks and distribution costs. The results showed that the supply of goods by the warehouse capacity that can fulfiil the necessary distribution product during a month amounted to 14.755 cartons. Optimal distribution for each destination, in Donggala are 8 trucks with a capacity of 250 cartons, Poso are 20 trucks with a capacity of 300 cartons and Ampana are 14 trucks with a capacity of 500 cartons. This result can save distribution costs of Rp.90.993.009 from the previous distribution costs of Rp. 282602.689.
\end{abstract}

Keywords : Cost Distribution, Goal Programming, Inventory, Truck Capacity.

\section{ABSTRAK}

Perusahaan distributor adalah perantara yang menyalurkan produk dari pabrik ke pengecer. Penelitian ini bertujuan untuk memaksimalkan pendistribusian dan penggunaan truk serta meminimumkan biaya pendistribusian. Goal Programming merupakan suatu metode yang dapat menyelesaikan masalah dengan lebih dari satu tujuan. Formulasi model Goal Programming terdiri dari 5 prioritas dan 5 fungsi kendala. Kelima prioritas tersebut adalah kapasitas gudang, jumlah truk yang digunakan untuk distribusi barang ke Donggala, Ampana, Poso, dan target biaya distribusi yang minimum. Fungsi kendala terdiri atas persediaan barang di gudang, banyaknya truk dan biaya distribusi. Hasil penelitian menunjukan bahwa pendistribusian barang berdasarkan kapasitas gudang yang dapat memenuhi kebutuhan penyaluran barang selama sebulan berjumlah 14.755 karton. Pendistribusian barang yang optimal pada masing-masing tujuan, di Donggala yaitu 8 kali pendistribusian menggunakan truk berkapasitas 250 karton, Poso 20 kali pendistribusian menggunakan truk berkapasitas 300 karton dan Ampana 14 kali pendistribusian menggunakan truk berkapasitas 500 karton. Model ini dapat menghemat biaya pendistribusian sebesar Rp.90.993.009 dari biaya distribusi yang sebelumnya yaitu Rp. 282.602.689.

Kata Kunci : Biaya Distribusi, Goal Programming, Persediaan Barang, Kapasitas Truk. 


\section{PENDAHULUAN}

\subsection{Latar Belakang}

Perusahaan adalah suatu organisasi yang didirikan seseorang atau sekelompok orang atau badan lain yang kegiatannya adalah melakukan produksi dan distribusi guna memenuhi kebutuhan ekonomis manusia. Kegiatan produksi pada umumnya dilakukan untuk memperoleh laba. Tujuan ekonomis memiliki tanggung jawab besar seperti tanggung jawab dalam mempertahankan eksistensi usaha, kualitas barang, dan kesejahteraan para pegawainya. Setiap perusahaan memerlukan rencana distribusi produk yang tepat agar terhindar dari kurang optimalnya pemasaran yang akan berdampak pada kerugian perusahaan.

PT.Wulantika Utama merupakan salah satu perusahaan distributor yang berada di Kota Palu yang menyalurkan produk (barang campuran) dari pabrikan ke berbagai toko, berupa: Pampers, Susu, Minuman Ion, Snack, Perlengkapan Mandi Anak, Obat Nyamuk, Tissue, Sabun Mandi, dan Larutan Penyegar. Pendistribusian produk ke berbagai toko dibatasi oleh permintaan dari masing-masing toko.

Dalam hal mendistribusikan produk (barang campuran) tersebut perusahaan masih saja mendapat kendala dalam meminimumkan total biaya transportasi. Masalah optimalisasi kinerja, PT.Wulantika menambahkan faktor-faktor seperti meminimasi biaya, jumlah truk yang akan digunakan untuk mengoptimalkan kapasitas angkut barang ke berbagai toko serta memaksimalkan keuntungan dari PT.wulantika itu sendiri. Usaha pencapaian tujuan yang beragam membutuhkan suatu metode analisis yang menghasilkan optimalisasi tujuan-tujuan tersebut. Salah satu diantaranya adalah Goal Programming.

Goal programming merupakan perluasan dari Linear Programing untuk mencapai tujuan atau target yang diinginkan. Aplikasi Goal Programming pertamanya dilakukan oleh Charnes dan Cooper (1961). Charnes dan Cooper mengembangkan pendekatan program tujuan untuk memperoleh solusi yang memuaskan, yang tidak bisa diperoleh dengan pendekatan Linear Programming karena adanya konflik atau penyimpanan antar tujuan. Analisis Goal Programming bertujuan untuk meminimumkan jarak antara atau deviasi terhadap tujuan, target atau sasaran yang telah ditetapkan dengan usaha yang dapat ditempuh. Untuk mencapai target atau tujuan tersebut secara optimal harus sesuai dengan syarat yang membatasinya berupa sumber daya yang tersedia, teknologi yang ada, kendala tujuan dan sebagainya (Vinsensia, 2009).

Berdasarkan latar belakang tersebut, penulis mencoba menuangkan masalah ini kedalam sebuah tugas akhir yang berjudul: "Optimalisasi Pendistribusian Barang dengan Menggunakan Metode Goal Programming (Studi Kasus: PT.Wulantika Utama)”. 


\subsection{Batasan Penelitian}

Adapun batasan masalah dalam penelitian ini yaitu :

1. Daerah tujuan yang menjadi jangkauan pendistribusian barang adalah daerah Donggala, Ampana dan Poso.

2. Persedian barang, Biaya distribusi dan jumlah truk yang diteliti berasal dari PT. Wulantika Utama.

3. Harga BBM yang digunakan yaitu harga pada tahun 2016.

\section{METODE PENELITIAN}

Berikut adalah prosedur penelitian yang akan dilakukan:

1. Mulai penelitian.

2. Studi literatur dilakukan dengan mengumpulkan materi dari buku, artikel, dan jurnal.

3. Pengambilan data.

4. Membangun model matematika dari data yang diperoleh.

5. Menyelesaikan model matematika tersebut menggunakan metode Goal Programming.

6. Menyimpulkanhasil penelitian.

7. Selesai.

III. HASIL DAN PEMBAHASAN

\subsection{Pengumpulan Data}

Adapun data yang diperoleh yaitu:

1. Kapasitas gudang barang PT.Wulantika Utama Kayumalue PT.Wulantika Utama memiliki 2 gudang dengan kapasitas 30.000 karton setiap gudangnya dengan luas masing-masing $2000 \mathrm{~m}^{2}$.

2. Permintaan dan persediaan barang tahun 2016

Tabel 1 : Permintaan dan Persediaan Barang Bulan April 2016

\begin{tabular}{|c|c|c|}
\hline Daerah Tujuan & Permintaan (karton) & Persediaan (karton) \\
\hline Donggala & 2.080 & 4.000 \\
\hline Poso & 6.070 & 12.000 \\
\hline Ampana & 7.095 & 14.000 \\
\hline Total & 15.245 & 30.000 \\
\hline
\end{tabular}

Sumber: PT. Wulantika Utama Kayumalue

3. Biaya Pendistribusian Barang

PT.Wulantika Utama Kayumalue melakukan distribusi barang dari gudang ke masing-masing toko dengan menggunakan truk berkapasitas 250 karton, truk 300 karton, truk 500 karton dengan pertimbangan biaya antara lain :
a. Upah Helper (buruh)
: Rp. 50.000/karton
b. Harga Bahan Bakar
:Rp. 5.400,-/Liter 
C. Asumsi Jumlah Bahan Bakar : 1L/15 km

Biaya pendistribusian barang PT. Wulantika Utama ke daerah tujuan dapat dilihat pada Tabel 2 :

Tabel 2 : Biaya Pendistribusian Barang

\begin{tabular}{|c|c|}
\hline Daerah Tujuan & $\begin{array}{c}\text { Biaya Pendistribusian Barang } \\
(\mathrm{Rp})\end{array}$ \\
\hline Donggala & 60.400 .050 \\
\hline Poso & 91.700 .462 \\
\hline Ampana & 130.502 .177 \\
\hline Total & 282.602 .689 \\
\hline
\end{tabular}

Sumber: PT.Wulantika Utama Kayumalue

4. Upah supir, upah buruh, harga Bahan Bakar dan biaya servis truk pengangkut barang perbulan.

Tabel 3 : Biaya Bahan Bakar yang Dibutuhkan Per Truk

\begin{tabular}{|c|c|c|c|c|}
\hline Daerah Tujuan & Jarak $(\mathrm{km})$ & $\begin{array}{c}\text { Jumlah } \\
\text { Solar }(\mathrm{L})\end{array}$ & $\begin{array}{c}\text { Harga } \\
(\mathrm{Rp})\end{array}$ & Total \\
\hline Donggala & 55 & 3,67 & 5.400 & 79.272 \\
\hline Poso & 194 & 12,93 & 5.400 & 558.576 \\
\hline Ampana & 500 & 33,33 & 5.400 & 1.439 .856 \\
\hline
\end{tabular}

Sumber: PT.Wulantika Utama Kayu

Tabel 4 : Truk I Kapasitas 250 karton

\begin{tabular}{|c|c|c|c|c|c|}
\hline $\begin{array}{c}\text { Daerah } \\
\text { Tujuan }\end{array}$ & $\begin{array}{c}\text { Upah } \\
\text { Supir (Rp) }\end{array}$ & $\begin{array}{c}\text { Upah Helper } \\
(\mathrm{Rp})\end{array}$ & $\begin{array}{c}\text { Bahan } \\
\text { Bakar Per } \\
\text { Truk (Rp) }\end{array}$ & $\begin{array}{c}\text { Biaya } \\
\text { Servis } \\
(\mathrm{Rp})\end{array}$ & Total (Rp) \\
\hline Donggala & 300.000 & 360.000 & 79.272 & 282.000 & 1.021 .272 \\
\hline Poso & 1.600 .000 & 1.720 .000 & 558.576 & 475.000 & 4.353 .576 \\
\hline Ampana & 1.600 .000 & 1.720 .000 & 1.439 .856 & 650.500 & 5.410 .356 \\
\hline
\end{tabular}

Sumber: PT.Wulantika Utama Kayumalue

Tabel 5 : Truk II Kapasitas 300 karton

\begin{tabular}{|c|c|c|c|c|c|}
\hline $\begin{array}{c}\text { Daerah } \\
\text { Tujuan }\end{array}$ & $\begin{array}{c}\text { Upah } \\
\text { Supir } \\
(\mathrm{Rp})\end{array}$ & $\begin{array}{c}\text { Upah } \\
\text { Helper (Rp) }\end{array}$ & $\begin{array}{c}\text { Bahan } \\
\text { Bakar Per } \\
\text { Truk (Rp) }\end{array}$ & $\begin{array}{c}\text { Biaya } \\
\text { Servis (Rp) }\end{array}$ & Total (Rp) \\
\hline Donggala & 300.000 & 400.000 & 79.272 & 340.000 & 1.119 .272 \\
\hline Poso & 1.600 .000 & 1.800 .000 & 558.576 & 520.000 & 4.478 .576 \\
\hline Ampana & 1.600 .000 & 1.800 .000 & 1.439 .856 & 790.000 & 5.629 .576 \\
\hline
\end{tabular}

Sumber: PT.Wulantika Utama Kayumalue 
Tabel 6 : Truk III Kapasitas 500 karton

\begin{tabular}{|c|c|c|c|c|c|}
\hline $\begin{array}{c}\text { Daerah } \\
\text { Tujuan }\end{array}$ & $\begin{array}{c}\text { Upah Supir } \\
(\mathrm{Rp})\end{array}$ & $\begin{array}{c}\text { Upah } \\
\text { Helper (Rp) }\end{array}$ & $\begin{array}{c}\text { Bahan } \\
\text { Bakar Per } \\
\text { Truk (Rp) }\end{array}$ & $\begin{array}{c}\text { Biaya } \\
\text { Servis } \\
(\mathrm{Rp})\end{array}$ & Total (Rp) \\
\hline Donggala & 300.000 & 560.000 & 79.272 & 479.000 & 1.418 .272 \\
\hline Poso & 1.600 .000 & 2.120 .000 & 558.576 & 890.000 & 4.968 .576 \\
\hline Ampana & 1.600 .000 & 2.120 .000 & 1.439 .856 & 1.745 .000 & 6.704 .856 \\
\hline
\end{tabular}

Sumber: PT.Wulantika Utama Kayumalue

\subsection{Penentuan Variabel Keputusan}

Variabel keputusan dinyatakan dengan:

$X_{1}=$ Banyaknya pendistribusian per bulan

$X_{2}=$ Banyaknya pendistribusian barang ke Donggala

$X_{3}=$ Banyaknya pendistribusian barang ke Poso

$X_{4}=$ Banyaknya pendistribusian barang ke Ampana

\subsection{Fungsi Tujuan dan Kendala Tujuan}

Setelah menentukan prioritas dan urutannya, fungsi tujuan yang terbentuk adalah:

$$
\begin{aligned}
\mathrm{Z}= & P_{1}\left({d_{1}}^{+}+{d_{1}}^{-}\right)+P_{2}\left(d_{2}{ }^{+}+{d_{2}}^{-}\right)+P_{3}\left(d_{3}{ }^{+}+{d_{3}}^{-}\right)+P_{4}\left(d_{4}{ }^{+}+d_{4}{ }^{-}\right)+ \\
& P_{5}\left(d_{5}{ }^{+}+d_{5}{ }^{-}\right)
\end{aligned}
$$

Kendala tujuan:

1. Kendala tujuan 1 (truk berkapasitas 250 karton):

$$
\begin{aligned}
15.245 X_{1}+d_{1}^{-}-d_{1}^{+} & =30.000 \\
250 X_{2}+d_{2}^{-}-d_{2}^{+} & =2.080 \\
250 X_{3}+d_{3}^{-}-d_{3}^{+} & =6.070 \\
250 X_{4}+d_{4}^{-}-d_{4}^{+} & =7.095
\end{aligned}
$$

$$
\begin{gathered}
R p .1 .021 .272 X_{5}+R p .4 .353 .576 X_{6}+R p .5 .410 .356 X_{7}+ \\
d_{5}^{-}-d_{5}^{+}=R p .282 .602 .689
\end{gathered}
$$

2. Kendala tujuan 2 (truk berkapasitas 300 karton)

$$
\begin{gathered}
15.245 X_{1}+d_{1}^{-}-d_{1}^{+}=30.000 \\
300 X_{2}+d_{2}^{-}-d_{2}^{+}=2.080 \\
300 X_{3}+d_{3}^{-}-d_{3}^{+}=6.070 \\
300 X_{4}+d_{4}^{-}-d_{4}^{+}=7.095
\end{gathered}
$$

$R p .1 .119 .272 X_{5}+R p .4 .478 .576 X_{6}+R p .5 .629 .576 X_{7}+$

$$
d_{5}^{-}-d_{5}^{+}=R p .282 .602 .689
$$


3. Kendala tujuan 3 (truk berkapasitas 500 karton)

$$
\begin{gathered}
15.245 X_{1}+d_{1}^{-}-d_{1}^{+}=30.000 \\
500 X_{2}+d_{2}^{-}-d_{2}^{+}=2.080 \\
500 X_{3}+d_{3}^{-}-d_{3}^{+}=6.070 \\
500 X_{4}+d_{4}^{-}-d_{4}^{+}=7.095 \\
R p .1 .418 .272 X_{5}+R p .4 .968 .576 X_{6}+R p .6 .704 .856 X_{7}+ \\
d_{5}^{-}-d_{5}^{+}=R p .282 .602 .689
\end{gathered}
$$

\subsection{Penyelesaian Goal Programming Menggunakan Aplikasi QM For Windows}

\subsubsection{Kendala Tujuan 1 (truk berkapasitas 250 karton)}

Untuk biaya yang minimum berdasarkan jumlah kendaraan optimal, maka nilai yang digunakan adalah $X_{2}=8, X_{3}=24, X_{4}=28$ $R p \cdot 1.021 .272(8)+R p \cdot 4.353 .576(24)+R p \cdot 5 \cdot 410.356(28)+$

$$
d_{5}^{-}-d_{5}^{+}=282.602 .689
$$

$R p .8 .170 .176+R p .104 .485 .824+R p .151 .489 .968+$

$$
d_{5}^{-}-d_{5}^{+}=282.602 .689
$$

$R p .264 .145 .968 d_{5}^{-}-d_{5}^{+}=282.602 .689$

Jumlah rupiah dimana target biaya distribusi kurang dari biaya distribusi yang ditetapkan PT.Wulantika Utama, sehingga didapatkan nilai $d_{5}^{-}=R p .18 .456 .721$

\subsubsection{Kendala Tujuan 2 (truk berkapasitas 300 karton)}

Untuk biaya yang minimum berdasarkan jumlah kendaraan optimal, maka nilai yang digunakan adalah $X_{2}=6, X_{3}=20, X_{4}=23$ $R p .1 .119 .272(6)+R p .4 .478 .576(20)+R p .5 .629 .576(23)+$

$$
d_{5}^{-}-d_{5}^{+}=282.602 .689
$$

$R p .6 .715 .632+R p .89 .571 .520+R p .129 .480 .248+$

$$
d_{5}^{-}-d_{5}^{+}=282.602 .689
$$

$R p .225 .767 .400 d_{5}^{-}-d_{5}^{+}=282.602 .689$

Jumlah rupiah dimana target biaya distribusi kurang dari biaya distribusi yang ditetapkan PT. Wulantika Utama, sehingga didapatkan nilai $d_{5}^{-}=$ Rp. 56.835.289

\subsubsection{Kendala Tujuan 3 (truk berkapasitas 500 karton)}

Untuk biaya yang minimum berdasarkan jumlah kendaraan optimal, maka nilai yang digunakan adalah $X_{2}=4, X_{3}=12, X_{4}=14$

$$
\begin{gathered}
R p .1 .418 .272(4)+R p .4 .968 .576(12)+R p .6 .704 .856(14)+ \\
d_{5}^{-}-d_{5}^{+}=282.602 .689 \\
R p .5 .673 .088+R p .59 .622 .912+R p .93 .867 .984+ \\
d_{5}^{-}-d_{5}^{+}=282.602 .689 \\
R p .159 .163 .984 d_{5}^{-}-d_{5}^{+}=282.602 .689
\end{gathered}
$$

Jumlah rupiah dimana target biaya distribusi kurang dari biaya distribusi yang ditetapkan PT. Wulantika Utama, sehingga didapatkan nilai $d_{5}^{-}=$ Rp. 123.438.705 


\subsection{Pembahasan}

Menurut Arif (2012), variabel deviasi atau jarak antara merupakan perbedaan yang khusus membedakan antara Linier Programming dan Goal Programming.Variabel deviasi mempunyai fungsi sebagai penampung terhadap tujuan-tujuan yang dikehendaki yang dibedakan menjadi dua bagian yaitu deviasi positif $\left(d^{+}\right)$untuk menampung deviasi yang berada di atas tujuan yang dikehendaki, maka $d^{+}$akan selalu berkoefisien -1 pada setiap kendala tujuandan deviasi negatif $\left(d^{-}\right)$untuk menampung deviasi yang berada di bawah tujuan yang dikehendaki, maka $d^{+}$akan selalu berkoefisien +1 pada setiap kendala tujuan. Dalam perumusan $G P$ dinyatakan faktor prioritas tersebut sebagai $P_{i}$ (untuk $i=1,2, \ldots, m$ ). Faktor-faktor prioritas tersebut memiliki hubungan sebagai berikut: $P_{i}>P_{2}>P_{i+1}$ Model umum dari Goal Programming adalah:Minimumkan: $Z=\sum_{i=1}^{m} P_{i}\left(d_{i}^{+}+d_{i}^{-}\right)$.

Berdasarkan jumlah truk optimal, untuk mendistribusikan barang campuran didaerah Donggala, Poso dan Ampana menggunakan truk berkapasitas $250 \mathrm{k}$, maka diperoleh biaya distribusi optimal yaitu sebesar Rp. 264.145.968 dimana biaya distribusi sebelumnya yaitu sebesar Rp. 282.602.689, maka $d_{5}^{-}=R p .18 .456 .721$ atau biaya distribusi dapat dihemat sebesar Rp. 18.456.721. Sedangkan dengan menggunakan truk berkapasitas $300 \mathrm{k}$, maka biaya distribusi optimalnya adalah Rp. 225.767 .400 dan menghasilkan $d_{5}^{-}=R p .56 .835 .289$ atau biaya distribusi dapat dihemat sebesar Rp.56.835.289. Begitupula halnya dengan mengunakan truk berkapasitas $500 \mathrm{k}$, biaya distribusi optimal yang diperoleh Rp. 159.163.984 dan menghasilkan $d_{5}^{-}=R p .123 .438 .705$ atau biaya distribusi dapat dihemat sebesar Rp. 123.438.705.

Namun setelah dilakukan kombinasi-kombinasi jumlah truk optimal untuk menyalurkan barang campuran di daerah Donggala, Poso dan Ampana maka diperoleh biaya distribusi yang paling optimal yaitu sebesar Rp. 191.609 .680 dimana biaya distribusi sebelumya yaitu Rp.282.602.689, maka biaya distribusi dapat dihemat sebesar Rp.90.993.009 dengan 8 kali pendistribusian menggunakan 2 truk berkapasitas $250 \mathrm{k}$, daerah Poso 20 kali pendistribusian dengan menggunakan 2 unit truk berkapasitas $300 \mathrm{k}$ dan 14 kali distribusi menggunakan 10 unit truk berkapasitas $500 \mathrm{k}$ ke daerah Ampana. Selain penghematan biaya distribusi, kombinasi ini juga menguntungkan dalam segi waktu karena penggunaan truk yang optimal.

\section{KESIMPULAN}

Berdasarkan penelitian dan uraian-uraian pada bab-bab sebelumnya, maka dapat disimpulkan bahwa:

1. Banyaknya pendistribusian truk optimal untuk mendistribusikan barang di daerah Donggala yaitu 8 kali pendistribusian dengan menggunakan 2 truk berkapasitas $250 \mathrm{k}$ dengan jumlah yang harus didistribusikan yaitu $2.080 \mathrm{k}$, daerah Poso 20 kali pendistribusian dengan menggunakan 2 unit truk berkapasitas $300 \mathrm{k}$ dengan jumlah yang harus didistribusikan yaitu 
$6.070 \mathrm{k}$ dan 14 kali distribusi menggunakan 10 unit truk berkapasitas $500 \mathrm{k}$ ke daerah Ampana dengan jumlah yang harus didistribusikan yaitu $7.095 \mathrm{k}$. Sehingga waktu yang diperlukan untuk pendistribusian barang yaitu 2 hari untuk daerah Donggala, 10 hari untuk daerah Poso dan 4 hari untuk daerah Ampana.

2. Biaya distribusi optimal adalah Rp. 191.609 .680 dimana biaya distribusi sebelumnya Rp. 282.602.689 sehingga dapat menghemat sebesar Rp. 90.993.006.

\section{DAFTAR PUSTAKA}

[1] Arif, M., Model Optimasi Persediaan Bahan Bakar Minyak (BBM) pada Pertamina UPMS VII Depot Donggala dengan Menggunakan Metode Goal Programming, 2012, Fakultas MIPA Universitas Tadulako, Palu.

[2] Damanik, E., Penerapan Metode Goal Programming untuk Mengoptimalkan Produksi Teh (studi kasus PT. Perkebunan Nusantara IV- Pabrik Teh Bah Butong), 2013, Fakultas MIPA Universitas Sumatera Utara, Medan.

[3] Raisan, F., Optimalisasi Pendistribusian Beras di Penggilingan Padi Kardi Jaya Utama Tolai dengan Menggunakan Metode Goal Programming, 2015, Fakultas MIPA Universitas Tadulako, Palu.

[4] Lasmanah, S.E., Goal Programming Sebagai Alat Bantu Manejemen dalam Memperkirahkan Target Perusahaan, 2003.

[5] Vinsensia, D., Studi Tentang Goal Programming dengan Pendekatan Optimasi Robust. Fakultas MIPA Universitas Sumatera Utara, 2009, Medan. 